\title{
A Structural Equation Model for Polygamy Review in Islamic Education of Parepare City
}

\author{
Iriani Ambar \\ Universitas Muhammadiyah Parepare \\ irianiambar18@gmail.com
}

\begin{abstract}
This study aims to identify the factors underlying the structural equation model of polygamy review in Islamic education and the most influential impact on the structural equation model of polygamy my review in the Islamic education of Parepare City, South Sulawesi Province. There were eight (8) participants in this study who were selected using purposive techniques based on the the characteristics of the subjects through clustering of four (4) subdistricts, namely Ujung, Soreang, Bacukiki and Bacukiki Barat.

This study used mixed method by combining between qualitative and quantitative methods with multi-case study approach through Structural Equation Model (SEM). The results of this study indicate that the issue of polygamy frequently leads to polemics and raises a variety of opinions among the public. The image of a polygamous family certainly invites controversy and depicts the heartbreaking story behind the marriage. Polygamy may result in wives lose their sense of trust in their husbands, increase suspicion and jealousy, children experience emotional suffering for mutual love, lack of attention, hatred and even economic downturn.

Thus, the decision to do or not to do polygamy is mostly based on the idea that whether polygamy bringsmore advantages or disadvantages regardless of the permissibility by law and religious law.
\end{abstract}

\section{Keywords: SEM, Polygamy, Law of Marriage}

\section{INTRODUCTION}

The marriage suggested by Islam is monogamous marriage and conditional polygamy, which includes a revelation of the faithful and loving promise made by husband and wife. This reflects the sociological reality of men and the patriarchal-Arab culture accommodated and modified by Islam. This concept is adopted by many Islamic countries, including Indonesia. Law No.1 Year 1974 states that the principle of marriage is monogamy, and polygamy is only allowed under strict conditions and certain circumstances. Similarly, as stipulated in the Compilation of Islamic Law (KHI), a marriage must hold the principle of monogamy, and polygamy is only permitted under special circumstances, or as the fulfillment of several conditions that have been predetermined. The
Government Regulation No.10 of 1983 and Government Regulation no. 45 of 1990 regulate the permissibility of polygamy with a fairly strict requirement for Civil Servants (PNS). However, although it has strong legal and theological foundations, it seems that the practice of polygamy frequently invites controversy for some people. Besides, the discourse on polygamy not only appeals to men who make it an obsession for life, but also for women who consider polygamy something that harms her position in the marriage.

Almost no one denies the existence of polygamy in the Qur'an. All scholars, both classical and modern ones, always depart from the basic framework of the Qur'an when discussing polygamy. Interestingly, although everyone departs from the same rationale, the outcomes tend to vary, even in contradiction to one another.

According to Khaled Abou el Fadl [1], no one can deny the fact that divine instructions always rely on text. Meanwhile, the text always rests on a means (language). It is this language which then becomes the source of crossreferences all the time. This is because language is nothing but a community agreement and a creation of human culture. To be understood, language depends on a symbol system that extremely needs the support of certain associations, images, as well as the emotions of listeners who are likely to change over time.

Khaled [1] adds that the real problem is not the different opinions; instead, a reader sometimes tries to neglect the text and force a single interpretation. To avoid this, Khaled offers five conditions that every reader must meet so as not to express his opinion arbitrarily, namely 1) able to control himself(self-restraint), 2) be earnest (diligent), 3) consider the related aspects (comprehensive), 4) be reasonable, and 5) be honest.

Khaled's statements above are relevant to understand the phenomena of the various interpretations of polygamyrelated verses. This is because polygamy has been causing controversy since centuries ago. Many books and articles have been written by scholars, but each expressed opinion always reflects certain associations and diverse emotional pictures between one reader and the other. In fact, when viewed from the legal aspect, polygamy is only a legal action in the category of ibahah (permissible), not sunah (recommended) let alone wajib(mandatory). In addition, the verses discussing the permissibility of polygamy are 
only fragments of verses from Quran Surah (chapter) An Nisaa verse 3. It seems plausible that if polygamy were sunah and there were more verses talking about it, Muslims would pay too much attention to this classic issue.

\section{STATEMENT OF THE PROBLEM}

Based on the above background, the research problems are formulated as follow:

1) Factors underlying the structure of the model equation of polygamy in Islamic education of Parepare City.

2) The most influential impact on the structure of the model equation of polygamy in Islamic education of Parepare City.

\section{RESEARCH METHODS}

The structural equation model tests the truth by proving the relevance of variables in seeking truth through theoretical and empirical constructs. This is performed through its variables in the system of equations by including the observed variable. The observed variable is a variable that can be observed and measured. Theoretical variables are built on the relevant rationality of a number of observed variables. The model construct assumes that there is a causal structure among a number of observed variables used as indicators or Simpsons of particular variables.

This study used questionnaires to collect data.

The population and sample involved in this research is people who are considered suitable and understand the structural equation model in Islamic education in Parepare City

The primary data were obtained through interviews and questionnaires, while the secondary data through elements contained in the four sub-districts: Sub Ujung, Soreang, Bacukiki and West Bacukiki.

The data obtained were first classified and tabulated, then processed with an analysis of the structural equation model (SEM). That is, the researcher analyzed the factors needed for consideration of the interpretative structural model of polygamy review in Islamic education and the most influential impact on the interpretative structural model of polygamy review in the Islamic education in Parepare City.

\section{RESULTS}

Structural Equation Model for polygamy review in Islamic education is largely undertaken by society by no longer focusing on humanitarian and justice missions. This is indicated by the number of domestic violence (KDRT) and practices of polygamy sirri (unregistered marriage) with more than four wives. Therefore, the ulama (Islamic scholar) and the government need to work together to restore the concept of polygamy that fits its original objectives. The good synergy between the ulama and the government will be manifested in various laws and regulations, which combine between the ulama thinking and the actual situation of polygamy practices. The inclusion of polygamy into legislation proves that there has been an increase in the public awareness of the importance of legalization in Islamic education and marriage life, especially regarding the government's control of the polygamy practice. At this point, the issue of polygamy seems to have been resolved. In fact, there are still many problems that have not been solved, such as disobedient society, ambiguous regulation, and inadequate information for the society regarding this matter.

In the author's perspective, a creative effort that can be made to restore the polygamy position as a solution to some problems that occur in the society is to impose tougher requirements of polygamy as practiced by modern scholars and some other Muslim countries. In this case, the existing problem does not necessarily mean that polygamy and the laws governing them are no longer irrelevant nor should it be abolished. Instead, it should be understood as part of legal facts, then used as a reference for continuous reformation.

One of the fundamental reasons to resist the abolition of polygamy is because polygamy can sometimes be the only solution to the problems faced by married couples. Quraish Shihab argued that polygamy issue should not be merely viewed from the good or bad side, but it must be seen from its legal provisions and all conditions that may occur in marriage life. The infertility of a wife, wife infected with severe illness or a wife cannot fulfill her obligations is among the possible conditions, which certainly requires a solution. In this case, Islam offers polygamy as a possible solution, as well as allows a husband to divorce his wife. However, the latter solution seems less preferable in Islam. In addition, the prohibition of polygamy in other countries like Turkey, Tunisia or Lebanon is closely related to their socio-political context. For example, although Tunisia has officially declared its independence and declared itself a Democratic Republic, but in implementing the law, it still adapts some of the rules of pre-independence law (colonial law). In the case of polygamy, the Tunisian government through the Code of Personal Statutes strictly prohibits and punishes those who violate it. In 1964, the Tunisian government not only punished polygamists, but regarded polygamous marriage as an illegitimate marriage. The regulation that prohibits polygamy practice in Tunisia cannot be separated from Habib Bourguiba, the President of Tunisia. Habib Bourguiba is a Tunisian figure who has been influenced by European thinking and education system, especially France. However, the legal reform practiced under his administration does not necessarily adopt the French legal system. Instead, he made a proportional combination between Islamic law and the spirit of renewal inspired by the French government. 


\section{REFERENCES}

[1] El Fadl, K. A. Atas Nama Tuhan, translated by R. Cecep Lukman Yasin (Jakarta: Serambi, 2003): Pusat Studi Gender STAIN Purwokerto, Vol. 5 No. 1 Jan-Jun 2010.

[2] At-Tuwaijiri, Muhammad bin Ibrahim bin Abdullah, Ensiklopedia Islam Al-Kamil, Jakarta: Darus Sunnah Press, 2010
[3] Aziz, Erwati, Isteri dalam perspektif al Quran, dalam Relasi Gender dalam Islam, Surakarta: Pusat Studi Wanita STAIN; Surakarta Press: 2002

[4] Katsir, Abu al Fida' Ibn. Qashashul al Anbiya'. Diterjemahkan oleh M. Abdul Ghoffar, EM., dengan judul "Kisah Para Nabi", Jakarta: Pustaka Azzam, 2001

[5] Nata, Abuddin, Metodologi Studi Islam, Jakarta:Rajawali Press, 2001) 